TEME, г. XLIV, бр. 4, октобар - децембар 2020, стр. 1261-1274

\begin{tabular}{lr}
\hline \hline Оригинални научни рад & https://doi.org/10.22190/TEME190321077R \\
Примљено: 21. 3. 2019. & UDK 316.74:028.01-057.874 \\
Ревидирана верзија: 19. 4. 2019. & $316.74: 37$ \\
Одобрено за штампу: 1. 12. 2020. &
\end{tabular}

\title{
RELATIONAL IMPACT OF CULTURAL CAPITAL AND THE PERCEPTION OF SELF-EFFICACY ON EDUCATIONAL ACHIEVEMENT
}

\author{
Vesna Rodić Lukić, Mia Marić, Snežana Štrangarić
}

University of Novi Sad, Faculty of Education in Sombor, Sombor, Serbia

*snezanajelacic@yahoo.com

\begin{abstract}
This paper aimed to examine the relationship between cultural capital in its three forms (objectified, embodied and institutionalized), the perceptions of students' self-efficacy and their achievements on the PISA test. The sample consisted of 4843 high school students enrolled in the PISA study in 2009. The results confirmed the existence of the proposed relationships. Self-efficacy and cultural capital significantly contribute to the prediction of student achievements, whereby the embodied cultural capital significantly contributes to the prediction of the perception of self-efficacy. Since the obtained relationships are not of high intensity, it can be concluded that other factors play a significant role in the development of students' self-efficacy and achievement. Practical implications would relate to activities of encouraging reading habits among students in order to increase the cultural capital and self-efficacy, which will have an effect on their achievement.
\end{abstract}

Key words: cultural capital, scientific literacy, PISA, self-efficacy.

\section{РЕЛАЦИОНИ УТИЦАЈИ КУЛТУРНОГ КАПИТАЛА И ПЕРЦЕПЦИЈЕ САМОЕФИКАСНОСТИ НА ОБРАЗОВНО ПОСТИГНУЋЕ УЧЕНИКА}

\section{Апстракт}

Циљ овог рада је испитивање односа између културног капитала у његова три облика (опредмећени, отеловљени и институционализовани), перцепције самоефикасности ученика и постигнућа ученика на ПИСА тесту. Узорак је чинило 4843 ученика средњих школа обухваћених ПИСА студијом из 2009. године. Резултати су потврдили постојање испитиваних релација - самоефикасност и културни капитал значајно доприносе ученичким постигнућима, при чему отеловљени културни капитал значајно доприноси и перцепцији самоефикасности ученика. Како добијене везе нису високог интензитета, може се закључити да и други чиниоци имају улогу у развоју самоефикасности и постигнућа код ученика. Практичне импликације односиле би се на активности усмерене ка повећању доступности различитих предмета за културно-едукативну потрошњу и развоју читалачких навика код свих ученика, у циљу 
акумулације културног капитала и раста самоефикасности, а самим тим и постигнућа ученика.

Кључне речи: културни капитал, научна писменост, ПИСА, самоефикасност.

\section{INTRODUCTION}

Programme for International Student Assessment (PISA) examines whether 15-year-old students who complete the general education phase have acquired the knowledge and skills necessary for continuing their education, professional development and responsible participation in the community (Baucal, 2012a; Baucal, 2012b; Baucal \& Pavlović-Babić, 2009; Rychen \& Salganik, 2003). The tasks set in front of students are not related to the degree to which students can reproduce content within a curriculum, but the emphasis was on assessing whether they have adopted applicable knowledge and mastered effective learning strategies. Also, it is aimed at the assessment of their ability to take a critical attitude towards different content and whether they can adapt applications in a number of different situations.

In the PISA study, the discussion is primarily based in terms of competence development in the fields of reading, mathematics and scientific literacy, and not regarding content, knowledge and skills acquisition. That means that the importance of applying the knowledge acquired in everyday situations is emphasized. This is considered to be primary educational capital necessary for further education and participation in the social environment (OECD, 2010). According to this, all the tasks used in the tests are related to real-life situations that require finding the solution (Baucal, 2012a).

The PISA study also uses additional questionnaires for students and schools, which collect data on various factors that may be related to school achievements, such as the material and educational resources of the family of students, the perception of their self-efficacy, strategies and habits related to learning, but also data on various aspects of school functioning (Baucal, 2012a; OECD, 2010).

Within the PISA questionnaire for students, there are also data about the cultural and socio-economic resources available within the family of students. In that way, the secondary analysis of the PISA study enables the measurement of the cultural capital in all its forms, on a large and representative sample of respondents (Andersen \& Jaeger, 2015; Barone, 2006; Chiu \& Chow, 2010; Tramonte \& Willms, 2010). The theory of cultural capital, although criticized for various interpretations and conceptual ambiguities (Goldthorpe, 2007; Kingston, 2001; Sullivan, 2002) has had a prominent place in the research of educational inequalities for a number of years. The results of numerous empirical studies have confirmed the positive effects of the cultural capital on the competence of students and their grades (Aschaffenburg \& Mass, 1997; DiMaggio, 1982; DiMaggio \& Mohr, 1985; 
Dumais, 2002; Sullivan, 2001; Štrangarić, Rodić Lukić \& Marić, 2017; Marić, Rodić Lukić \& Štrangarić, 2018).

French sociologist Pierre Bourdieu founded the theory of cultural capital in the second half of the $20^{\text {th }}$ century. Bourdieu identifies the school as one of the fundamental institutions through which the existing social hierarchy is maintained systematically and reproduces social inequalities precisely through cultural capital (Bourdieu, 1973; Bourdieu \& Passeron, 1990; Bourdieu, 2011; Bourdieu and Paseron, 2014). The members of high socio-economic status possess cultural capital, as well as other forms of capital, and it is transmitted intergenerationally. That means that children, during the process of preschool socialization, inherit and adopt certain cultural habits, style and cultural codes from their parents, which provides an initial advantage in the educational system and better success, in comparison to the children from lower social strata. Students who originate from lower social strata are less likely to adapt to the educational system due to the lack of social power and unequal distribution of capital in the social hierarchy, which reflects on their success at school and, therefore, in society. According to Bourdieu, education does not have the role of a social mobility channel, but a latent function of maintaining social inequalities. On the foundations of Bourdieu's theoretical model of social and cultural reproduction, American sociologist Paul DiMaggio (1982) also believes that cultural capital is linked to educational achievement, but that its relations with socio-economic status are more complex, so he develops a different point of view. In his model of cultural mobility, DiMaggio argues that the possession of cultural capital is not the exclusive privilege of the higher social strata and that the members of lower social strata can have the most usefulness from its accumulation for their educational success. The results of some empirical studies support the theory of cultural mobility (Andresen \& Jaeger, 2015; Aschaffenburg \& Mass, 1997; De Graaf, De Graaf \& Kraaykamp, 2000; Dumais, 2006).

The testing of cultural capital involves the measurement of its three distinct but interrelated forms: objectified, embodied and institutionalized (Bourdieu, 1986). An objectified form of cultural capital implies the possession of material goods for cultural consumption, such as books, paintings, sculptures or musical instruments. In one of the secondary analyses of the PISA study, it was found that the possession of books has a significant impact on educational achievement (Evans, Kelley, Sikora \& Treiman, 2014). Further, the embodied cultural capital is defined as a system of long-lasting dispositions of the mind and body which is created by the pedagogical action of the parents during the socialisation process (Brubaker, 1985; Cvetičanin, 2012). As such, the embodied form of cultural capital is problematic for operationalisation (Štrangarić, 2017). In empirical research of educational inequalities, the readers' habits and participation in public cultural events are most often taken for its indicators, therewith 
results of the research showing that reading activities have a greater impact on the educational achievement (Chiu \& Chow, 2010; De Graaf , 1986; De Graaf et al., 2000; Sullivan, 2001; Sullivan \& Brown, 2013). The third form of cultural capital identified as institutionalized cultural capital implies the possession of diplomas and titles, that is, academic qualifications, and thus represents the outcome of the first two forms.

\section{Perception of Students'Self-efficacy, Cultural Capital and Educational Achievement}

The person's self-effective beliefs act primarily on the self-regulation of motivation. The effect of our beliefs on what we are able, and what we are not able to do, is very important. Especially so if we bear in mind that cognitive processes lie at the basis of a greater part of the motivation, and it increases, if we are convinced of the success of the realisation of our goals (Ashford \& LeCroy, 2010; Earley, Gibson, \& Chen, 1999; Pajares \& Schunk, 2001).

The original concept of self-efficacy in Alberto Bandura's theory (1977) represents a concrete and case-by-case related assessment of individual efficiency. Thus, there are specific types of self-efficacy assessments: assessment of self-efficacy in learning, in exam preparation, in performing certain activities and the like. It is precisely because of this fact that it is essential to include contextual factors in the examination of the outcome of self-efficacy (Bandura, 1993).

In the theory of self-efficacy, behaviour and motivation are the results of the interaction of individual, environmental, and behavioural factors (Bandura, 1977). The achievements of students are thus influenced by distinct possibilities, but also by the environment. When it comes to the analysis of factors related to achievements, it is essential to include the functioning of the socio-cultural environment of students, in the form of cultural capital (Linnenbrink \& Pintrich, 2003; Zimmerman, 2001).

There are studies about the factors of self-efficacy, which are mostly conducted examining the children growing up in unfavourable socio-cultural circumstances, that is, without appropriate social incentives and a low level of available cultural capital (Graham, 1994; Mayer, 2009; Schunk, \& Pajares, 2002; Pajares, 2009). Children from low-income families, with low cultural capital, underestimate their self-efficacy, and they are uncertain about their opportunities and potential.

The findings of the research confirm that socio-cultural, economic and family factors influence the development of the self-efficacy of children and young people (Bandura, Barbanelli, Capraro, \& Pastrelli, 2001; ČudinaObradović, 2014; Majer, 2009; Meshack, 2013). Also, the parental efforts and incentives act on the experience of self-efficacy in students (Lee, 2009; Milanović-Dobrota and Radić-Šestić, 2012). 
A comparative study of PISA testing results from 2012 in three countries - China, Turkey and Greece, confirmed the link between the socio-cultural index and educational opportunities provided by the family, on the one hand, and student self-efficacy, on the other hand in all three countries. It is thus stated that students who come from families with lower socio-cultural indexes and who provide educational opportunities for children have lower levels of self-efficacy (Usta, 2015).

Children growing up in a stimulating environment, in which they are encouraged to search for different information and to undertake a wide range of cultural and educational activities, who possess in their homes a large number of books, toys meant for education, a computer and similar materials and tools for learning and entertainment, and whose parents spend time with them in everyday educational activities will have an undoubtedly higher level of self-efficacy (Bogard, 2005; Meece, 1997; Schunk \& Pajares, 2009).

Research confirms that cultural capital in the family and school environment of students contributes positively to the development of the characteristics associated with school success and academic competencies, also by encouraging the self-efficacy experience (Brooks \& Van Noy, 2007; Perna, 2000; Perna \& Titus, 2005; Rowan-Kenyon, 2007).

\section{METHOD}

For research of cultural capital, self-efficacy and educational achievement, a secondary analysis of the empirical data collected within the PISA 2009 study was carried out. Primary research was conducted in April and May of 2009 at 151 schools in Serbia. The sample consisted of 4843 high school students aged 15 years. The gender structure was 2483 female and 2360 male respondents. The characteristics of the sample are shown in Table 1.

Cultural capital has been operationalised using indicators for its three forms, which were measured by items from the student's questionnaire. The items related to the father's educational level and their possession of academic qualifications are used to measure the institutionalized cultural capital. The number of books in the respondent's home and the possession of other objects for cultural consumption such as paintings and educational software are used to measure the objectified cultural capital. The reading habits of the respondents are used to measure the embodied cultural capital.

Educational achievement has been operationalized through achievements in the field of scientific literacy. Scientific literacy is measured by cognitive tests, which implies "possession of scientific knowledge and their application in recognition of scientific problems, acquiring new knowledge, scientific explanation of phenomena and performing factual 
conclusions on scientifically relevant issues" (Baucal \& Pavlović Babić, 2010: 31).

Table 1. Characteristics of the sample

\begin{tabular}{|c|c|c|c|c|c|}
\hline & & \multicolumn{4}{|c|}{ Gender } \\
\hline & & & Female & Male & Total \\
\hline \multirow{12}{*}{$\begin{array}{l}\text { Type of } \\
\text { secondary } \\
\text { education }\end{array}$} & \multirow{4}{*}{$\begin{array}{l}\text { General } \\
\text { educational }\end{array}$} & Frequency & 752 & 454 & 1206 \\
\hline & & $\%$ School type & $62.4 \%$ & $37.6 \%$ & $100.0 \%$ \\
\hline & & $\%$ Gender & $31.7 \%$ & $18.7 \%$ & $25.1 \%$ \\
\hline & & $\%$ Total & $15.6 \%$ & $9.4 \%$ & $25.1 \%$ \\
\hline & \multirow{4}{*}{$\begin{array}{l}\text { Secondary } \\
\text { vocational school } \\
\text { (four years) }\end{array}$} & Frequency & 1332 & 1381 & 2713 \\
\hline & & $\%$ School type & $49.1 \%$ & $50.9 \%$ & $100.0 \%$ \\
\hline & & $\%$ Gender & $56.1 \%$ & $56.8 \%$ & $56.4 \%$ \\
\hline & & $\%$ Total & $27.7 \%$ & $28.7 \%$ & $56.4 \%$ \\
\hline & \multirow{4}{*}{$\begin{array}{l}\text { Secondary } \\
\text { vocational school } \\
\text { (three years) }\end{array}$} & Frequency & 291 & 597 & 888 \\
\hline & & \% School type & $32.8 \%$ & $67.2 \%$ & $100.0 \%$ \\
\hline & & $\%$ Gender & $12.3 \%$ & $24.5 \%$ & $18.5 \%$ \\
\hline & & $\%$ Total & $6.1 \%$ & $12.4 \%$ & $18.5 \%$ \\
\hline \multirow{4}{*}{ Total } & & Frequency & 2375 & 2432 & 4807 \\
\hline & & \% School type & $49.4 \%$ & $50.6 \%$ & $100.0 \%$ \\
\hline & & $\%$ Gender & $100.0 \%$ & $100.0 \%$ & $100.0 \%$ \\
\hline & & $\%$ Total & $49.4 \%$ & $50.6 \%$ & $100.0 \%$ \\
\hline
\end{tabular}

The student's self-efficacy scale was in additional PISA questionnaire for students and included the following features: a) in comparison to my classmates and classmates, I'm pretty good in school, b) it's easy for me to understand most of the things that are learned at school c) considering all, I think that at the end of the year I will be completely satisfied with my school success, d) it is easy for me to force myself to learn, e) when I sit down, I learn everything easily, f) almost always I manage to master material without additional help, g) compared to others, learning is easy for me, h) I am convinced that I can learn. The perception of students' self-efficacy is expressed on a standardized scale, where 0 denotes the average level, and the values below and above zero show the self-efficacy below and above the average. The internal reliability of the used scale was checked by the Cronbach's Alpha coefficient $(\alpha=.831)$.

\section{RESULTS}

In order to examine the links between cultural capitals, self-efficacy and scientific literacy of students, three regression analyses were conducted, and preliminary analyses indicated that assumptions of normality, linearity and multicollinearity were not violated. 
Table 2. Descriptive statistics

\begin{tabular}{lcrrrc}
\hline & $\mathrm{N}$ & \multicolumn{1}{c}{ Minimum } & Maximum & Mean & Std. Deviation \\
\hline Scientific literacy & 4843 & -2.46 & 2.53 & -.022 & .82 \\
Self-efficacy & 4706 & 1.00 & 4.00 & 2.76 & .46 \\
Institutionalized capital & 4677 & .75 & 3.75 & 1.55 & .35 \\
Objectified capital & 4557 & 1.00 & 8.00 & 1.98 & .63 \\
Embodied capital & 4689 & 1.00 & 8.00 & 2.52 & .78 \\
\hline
\end{tabular}

Table 3. Correlations between variables

\begin{tabular}{lcccc}
\hline & $\begin{array}{c}\text { Self- } \\
\text { Efficacy }\end{array}$ & \multicolumn{2}{c}{ Scientific Institutionalized } & Objectified \\
citeracy & capital & capital \\
\hline Scientific literacy & $.070^{* *}$ & & & \\
Institutionalized capital & .015 & $.036^{*}$ & & \\
Objectified capital & $.060^{* *}$ & $.265^{* *}$ & $-.064^{* *}$ & \\
Embodied capital & $.215^{* *}$ & $.172^{* *}$ & -.014 & $.216^{* *}$ \\
\hline
\end{tabular}

**. Correlation is significant at the 0.01 level (2-tailed).

*. Correlation is significant at the 0.05 level (2-tailed).

In the first regression analysis, the variables of cultural capital (objectified, embodied and institutionalized) were set as independent variables, while the composite variable of self-efficacy was set as a dependent variable. The results indicated that the overall regression is statistically significant at $\mathrm{p}<.001$ and the components of cultural capital explain $5 \%$ of the variance of self-efficacy. Between these variables, there was slightly lower connection intensity. Taking into account the individual effects of the predictor (independent) variables, it can be concluded that the embodied cultural capital gave a unique statistically significant contribution to the prediction of the dependent variable, while the objectified and institutionalized cultural capital did not give a statistically significant contribution to the prediction. A positive sign in beta coefficient indicates that with the increase in embodied cultural capital, student self-efficacy increases.

Table 4. Relationships between cultural capital forms and self-efficacy

\begin{tabular}{llcccc}
\hline $\mathrm{R}=.221$ & $\mathrm{R}=71.900$ & & Sig. $\mathrm{F}=.000$ \\
\hline Num. & Dimensions & Beta & Part & $\mathrm{t}$-value & Sig. t \\
\hline 1. & Institutionalized capital & .028 & .028 & 1.883 & .060 \\
2. & Objectified capital & .021 & .020 & 1.348 & .178 \\
3. & Embodied capital & .214 & .209 & 13.921 & .000 \\
\hline
\end{tabular}

During the implementation of the second regression analysis, the composite variable of self-efficacy was set as the predictor, and the scientific competence (the total PISA score - scientific literacy) was set as 
a dependent variable. The results showed that the regression model was statistically significant at the level of $p<.001$. Between those variables there was slightly lower intensity of connection, and the composite selfefficacy variable explains .5\% of PISA score variance - scientific literacy.

Table 5. Relationships between students' self-efficacy and scientific literacy

\begin{tabular}{lccccc}
\hline $\mathrm{R}=.070$ & $\mathrm{R}^{2}=.05$ & $\mathrm{~F}=23.404$ & & \multicolumn{2}{c}{ Sig. $\mathrm{F}=.000$} \\
\hline Num. & Dimension & Beta & Part & t-value & Sig. $\mathrm{l}$ \\
\hline 1. $\quad$ Self-efficacy & .070 & .070 & 4.838 & .000 \\
\hline
\end{tabular}

During the implementation of the third regression analysis, the variables of cultural capital were set as the predictor variables, while the scientific competence was set as a dependent variable.

The results showed that the overall regression is statistically significant at the level of $p<.001$. Between these variables, there was a slightly lower intensity of connection, while the components of cultural capital explain $8.2 \%$ of PISA scores variance - scientific literacy. When it comes to the individual effects of the predictor variables, objectified and embodied cultural capital give an individual statistically significant contribution to the prediction.

Table 6. Relationships between cultural capital forms and scientific literacy

\begin{tabular}{llcccc}
\hline $\mathrm{R}=.287$ & $\mathrm{~F}=129.035$ & & Sig. $\mathrm{F}=.000$ \\
\hline Num. & Dimensions & Beta & Part & $\mathrm{t}$-value & Sig. $\mathrm{t}$ \\
\hline 1. & Institutionalized capital & .027 & .027 & 1.840 & .066 \\
2. & Objectified capital & .239 & .233 & 15.963 & .000 \\
3. & Embodied capital & .117 & .114 & 7.840 & .000 \\
\hline
\end{tabular}

\section{DISCUSSION}

The results showed that the increase of embodied cultural capital increases the students' self-efficacy, while the objectified and institutionalized cultural capital has not been shown to be a significant factor of students' selfefficacy. This result is mostly expected, given the findings of the previous studies which showed that children who grow up in an incentive-based cultural and educational environment, where parents encouraged them to search for different information and to take a broad spectrum of cultural and educational activities, at the same time have a higher level of selfefficacy (Bogard, 2005; Flouri \& Buchanan, 2004; Harris \& Goodall, 2008; Meece, 1997).

Only to some extent, it is surprising that the objectified cultural capital has not been shown to be associated with self-efficacy. This result suggests that the possession of cultural goods by itself is not enough to 
develop the experience of self-efficacy and does not have an incentive effect on children. On the other hand, it is necessary to practice culturaleducational activities by children, as well as the presence of culturallyconscious parents, as significant models for children's behaviour (Bandura, 1997). Also, the parents' role is to actively participate in organising various stimulating activities that contribute to the overall psychosocial development of children, encouraging their safety and self-confidence, autonomy and various interests (Bandura et al., 2001; Lee, 2009; Mayer, 2009; Meshack, 2013).

Self-efficacy of students proved to be an important factor in achieving PISA scientific literacy, and this speaks in favour of Bandura's theory of selfefficacy (Bandura, 1993) which within the educational domain highlights the importance of assessing students' effectiveness for learning success and development of individual competencies (Linnenbrink \& Pintrich, 2003; Zimmerman, 2001). Students' perceptions of success positively influence the process of self-regulation of motivation, encourages them to make greater efforts and maintain persistence in achieving goals, resulting in better achievement and greater competence development (Ashford \& LeCroy, 2010; Burke et al., 2009; 1999, Pajares \& Schunk, 2001).

Findings related to the connection between cultural capital and scientific literacy indicated that objectified and embodied cultural capital make a significant contribution to the prediction of student achievement in this field, while the objectified cultural capital was contributing more to the student achievement. Further, results indicated that mere availability of cultural goods is of utmost importance for the outcome - achievement and development of student competencies, which correspond to the results of previous studies (Evans et al., 2014; Schunk \& Pajares, 2009) that point to the importance of possessing the appropriate material and means for learning and entertainment that stimulate cognitive development. Namely, the possession of such means for the educational and cultural development of the child is one of the essential preconditions for their use, which also contributes to the development of students' competencies and the level of achievement. The obtained result is entirely expected and agrees with the findings of previous studies (Chiu \& Chow, 2010; Cvetičanin, 2012; De Graaff et al., 2000; Sullivan \& Brown, 2013) that confirm the importance of culturaleducational activities such as developing reading habits, visiting cultural events and the like, as well shaping the child's preferences and habits by the parents, in order to develop children competencies and the promotion of achievements in various fields.

Parental cultural habits are crucial for the development of tendencies, habits and interests in children since parents provide compelling models of shaping the child's characteristics and behaviours (Bandura, 1993). The cultural-educational efforts and behaviours of parents ultimately lead to the development of child's interests, aspirations for learning and improvement, 
which again leads to higher achievement and development of students' competencies in different domains (Aschaffenburg \& Mass, 1997; Dumais, 2002; Flouri \& Buchanan, 2004; Harris \& Goodall, 2008; Sullivan, 2001).

\section{CONCLUSION}

The research aimed at examining the links between cultural capital, self-efficacy and achievement of students on the PISA test, confirmed the existence of tested relationships. However, since the relationships between them were not strong, it can be concluded that other factors play a significant role in fostering student self-efficacy and competence development, and it would be worthwhile to include an examination of the impact of a larger number of internal and external factors in some of the future studies.

The data obtained through PISA surveys enable us to gain insight into the equity and efficiency of the educational system, monitoring the extent to which changes in education and the social context reflect on the level and quality of educational outcomes, and in accordance with the results, they plan educational policies and decide on future directions for the improvement of the educational system. The more specific strategies which can come out from this research would concern the provision of broader availability of various cultural education items such as books or educational software, as well developing reading and other cultural habits among all students, with the ultimate goal of fostering student selfefficacy and increasing educational achievement.

\section{REFERENCES}

Andersen, I.G. \& Jaeger, M.M. (2015). Cultural Capital in Context: Heterogeneous Returns to Cultural Capital across Schooling Environments. Social Science Research, 50, 177-188.

Aschaffenburg, K. \& Mass, I. (1997). Cultural and Educational Careers: The Dynamics of Social Reproduction. American Sociological Review, 62, 573-587.

Ashford, J. B., \& LeCroy, C. W. (2010). Human behaviour in the social environment: A multidimensional perspective (4th ed.). Belmont, CA: Wadsworth, Cengage Learning.

Bandura, A. (1977). Self-efficacy: Toward a unifying theory of behavioural change. Psychological Review, 84, 191-215.

Bandura, A. (1993). Perceived self-efficacy in cognitive development and functioning. Educational Psychologist, 28, 117-148.

Bandura, A. (1997). Self-efficacy: the exercise of control. New York: Stanford University, W.H. Freeman and Company.

Bandura, A. Barbanelli, C. Capraro, G.V., \& Pastrelli, C. (2001). Self-efficacy beliefs as shapers of children's aspirations and career trajectories. Child Development, $72,187-206$.

Barone, C. (2006). Cultural Capital, Ambition and the Explanation of Inequalities in Learning Oucomes: A Comparative Analysis. Sociology, 40(6), 1039-1058. 
Baucal, A. (2012a). Uticaj ekonomskog statusa na obrazovna postignuća: direktni i indirektni uticaji. Primenjena psihologija, 1, 5-24.

Baucal, A. (2012b). Ključne kompetencije mladih u Srbiji u PISA 2009 ogledalu. Beograd: Ministarstvo prosvete Republike Srbije i Institut za psihologiju.

Baucal, A. i Pavlović-Babić, D. (2009). Kvalitet i pravednost obrazovanja u Srbiji: obrazovne šanse siromašnih. Beograd: Ministarstvo prosvete Republike Srbije i Institut za psihologiju.

Baucal, A. i Pavlović-Babić, D. (2010). PISA 2009 u Srbiji: prvi rezultati - Nauči me da mislim, nauči me da učim. Beograd: Institut za psihologiju Filozofskog fakulteta u Beogradu i Centar za primenjenu psihologiju.

Bogard, K. (2005). Affluent adolescents, depression, and drug use: The role of adults in their lives. Adolescence, 40, 281-306.

Bourdieu, P. (1973). Cultural Reproduction and Social Reproduction. In: Brown, R. (Ed.) Knowledge, Education and Cultural Change. London: Tavistock, pp. 71-112.

Bourdieu, P. (1986). The forms of capital. In: Richardson, J. (Ed.) Handbook of Theory and Research for Sociology of Education (pp. 241-258). New York: Greenwood.

Bourdieu, P. (2011). Distinkcija: Društvena kritika suđenja. Zagreb: Antibarbarus. Bourdieu, P. \& Passeron, J. (1990). Reproduction in Education, Society and Culture. London: Sage publications.

Brooks, R. L., \& Van Noy, M. (2007). A study of self-esteem and self-efficacy as psychosocial educational outcomes: the role of high school experiences and influences. Retrieved on December 9, 2016 from http://www.texastop10. princeton.edu/conference/seminar08/Brooks_HighSchoolExperiences_v.01.pdf

Brubaker, R. (1985). Rethinking Classical Theory: The Sociological Vision of Pierre Bourdieu. Theory and Society, 14, 745-775.

Burdije, P. \& Paseron, Ž.K. (2014). Reprodukcija. Elementi za jednu teoriju obrazovnog sistema. Beograd: Fabrika knjiga.

Chiu, M. M. \& Chow, B. W. Y. (2010). Culture, motivation, and reading achievement: High school students in 41 countries. Learning and Individual Differences, 20, 579-592.

Cvetičanin, P. (Ed). (2012). Social and Cultural Capital in Serbia. Niš: Centre for Empirical Cultural Studies of South-East Europe.

Čudina-Obradović, M. (2014). Psihologija čitanja od motivacije do razumijevanja. Zagreb: Golden marketing - Tehnička knjiga.

DiMaggio, P. (1982). Cultural Capital and School Success: The Impact of Status Culture Participation on the Grades of U.S. High School Students. American Sociological Review, 47, 189-201.

DiMaggio, P. \& Mohr, J. (1985). Cultural Capital, Educational Attainment, and Marital Selection. American Journal of Sociology, 90, 1231-1261.

De Graaf, P.M. (1986). The Impact of Financial and Cultural Resources on Educational Attainment in the Netherlands. Sociology of Education, 59(4), 237-246.

De Graaf, N.D., De Graaf, P. \& Kraaykamp, G. (2000). Parental Cultural Capital and Educational Attainment in Netherlands: A Refinement of the Cultural Capital Perspective. Sociology of Education, 73, 92-111.

Dumais, S. (2002). Cultural Capital, gender and School Success: The Role of Habitus. Sociology of Education, 75, 44-68.

Dumais, S. (2006). Early childhood cultural capital, parental habitus, and teacher's perception, Poetics, 34, 83-107.

Earley, P. C., Gibson, C. B., \& Chen, C. C. (1999). "How did I do?" versus "How we do?": cultural contrasts of performance feedback use and self-efficacy. Journal of cross-cultural psychology, 30(5), 594-619. 
Evans, M.D., Kelley, J., Sikora, J. \& Treiman, D. (2010). Family Scholarly Culture and Educational Success: Books and Schooling in 27 nations. Research in Social Stratification and Mobility, 28(2), 171-197.

Flouri, E. \& Buchanan, A. (2004). Early father's and mother's involvement and child's later educational outcomes. British Journal of Educational Psychology, 74, 141-153.

Goldthorpe, J. (2007). Cultural Capital: Some Critical Observations. Sociologica, 2, 1-23.

Graham, S. (1994). Motivation in African Americans. Review of Educational Research, 64, 55-117.

Harris, A. \& Goodall, J. (2008). Do parents know they matter? Engaging all parents in learning. Educational Research, 50(3), 277 - 289.

Kingston, P. (2001). The Unfulfilled Promise of Cultural Capital Theory. Sociology of Education, 74, 88-99.

Lee, J. (2009). Universals and specifics of math concept, math self-efficacy and math anxiety 41 PISA 2003 participating countries. Learning and Individual Differences, 19, 355-365.

Linnenbrink, E. A., \& Pintrich, P. R. (2003). The role of self-efficacy beliefs in studentengagement and learning in the classroom. Reading and Writing Quarterly, 19, 119-137.

Majer, J. M. (2009). Self-efficacy and academic success among ethnically diverse first-generation community college students. Journal of Diversity in Higher Education, 2(4), 243-250. doi:10.1037/a0017852

Marić, M., Rodić Lukić, V. i Štrangarić, S. (2018). Model uticaja kulturnog kapitala i individualnih motivacionih činilaca na ključne kompetencije učenika. Primenjena psihologija, 11(1), 9-26.

Meece, J. L. (1997). Child and adolescent development for educators. New York: McGraw-Hill.

Meshack, E. O. (2013). The role of school and motivational factors in mathematics achievement and self-efficacy: a multi-level analysis. Cleveland: ETD Archive.

Milanović-Dobrota, B., Radić-Šestić, M. (2012). Značaj modela samoefikasnosti u vaspitno-obrazovnom radu sa adolescentima. Specijalna edukacija i rehabilitacija, 11(4), 637-655.

OECD (2010). PISA 2009 Results (Vol 1-5). Paris: OECD.

Pajares, F. (2009). Toward a positive psychology of academic motivation: The role of selfefficacy beliefs. In R. Gilman, E. S. Huebner \& M. J. Furlong (Eds.), Handbook of positive psychology in schools (pp. 149-160). New York: Taylor \& Francis.

Pajares, F. \& Schunk, D. (2001). Self-beliefs and school success: Self-efficacy, selfconcept, and school achievement. In R. Riding \& S. Rayner (Eds.), Perception (pp. 239-266). London: Ablex Publishing.

Perna, L.W. (2000). Differences in the decision to attend college among African Americans, Hispanics, and Whites. Journal of Higher Education, 71(2), 117-141.

Perna, L. W. \& Titus, M.A. (2005). The relationship between parental involvement as social capital and college enrollment: an examination of racial/ethnic group differences. Journal of Higher Education, 76(5), 485-518.

Rychen D. S., \& Salganik, L. H. (2003). Key competencies for a successful life and a well-functioning society. Cambridge: Hogrefe \& Huber.

Rowan-Kenyon, H.T. (2007). Predictors of delayed college enrollment and the impact of socioeconomic status. Journal of Higher Education, 78(2), 188-214.

Schunk, D. H., \& Pajares, F. (2002). The development of academic self-efficacy. In A. Wigfield \& J. Eccles (Eds.), Development of achievement motivation (pp.127). San Diego: Academic Press. 
Sullivan, A. (2001). Cultural Capital and Educational Attainment. Sociology, 35(4), 893-912.

Sullivan, A. (2002). Bourdieu and Education: How Useful is Bourdieu's Theory for Researchers? The Netherlands' Journal of Social Sciences, 38(2), 144-165.

Sullivan, A. \& Brown, M. (2013). Social inequalities in cognitive scores at age 16: The role of reading. London: Centre for Longitudinal Studies, Working Papers (13/10).

Štrangarić, S. (2017). Kulturni kapital i znanje: problemi operacionalizacije u istraživanjima obrazovnih nejednakosti. Sociološki pregled, 51(2), 300-323.

Štrangarić, S., Rodić Lukić, V. i Marić, M. (2017). Efekti kulturnog kapitala na obrazovna postignuća učenika - sekundarna analiza PISA studije. Nastava $i$ vaspitanje, 46(2), 207-219.

Tramonte, L. \& Willms, J. D. (2010). Cultural Capital and its Effects in Education Outcomes. Economic of Education Review, 29, 200-213.

Usta, H. G. (2015). Analysis of student and school level variables related to mathematics self-efficacy level based on PISA 2012 results for China-Shanghai, Turkey, and Greece. Educational sciences: Theory and practice, 16(4), 1297-1323.

Zimmerman, B. J. (2001). Theories of self-regulated learning and academic achievement: An overview and analysis. Self-regulated learning and academic achievement: Theoretical perspectives (2nd ed.), (pp. 1-37). Mahwah, NJ: Lawrence Erlbaum Associates Publishers.

\title{
РЕЛАЦИОНИ УТИЦАЈИ КУЛТУРНОГ КАПИТАЛА И ПЕРЦЕПЦИЈЕ САМОЕФИКАСНОСТИ НА ОБРАЗОВНО ПОСТИГНУЋЕ УЧЕНИКА
}

\author{
Весна Родић Лукић, Миа Марић, Снежана Штрангарић \\ Универзитет у Новом Саду, Педагошки факултет, Сомбор, Република Србија
}

\section{Резиме}

Теорији културног капитала, коју је утемељио француски социолог Пјер Бурдиje, припада истакнуто место у истраживањима образованих неједнакости. Бурдије је идентификовао школу као једну од темељних институција путем које се системски одржавају постојеће друштвене хијерархије и која репродукује друштвене неједнакости управо путем културног капитала, а велики број емпиријских студија насталих на линији његовог наслеђа потврдио је позитивне ефекте културног капитала на компетенције и образовно постигнуће ученика.

У оквиру теорије самоефикасности, понашање и мотивација представљају резултат интеракције индивидуалних и бихевиоралних чинилаца, као и фактора окружења. Када је у питању анализа чинилаца који утичу на образовно постигнуће, значајно је укључити елементе који се односе на социокултурно окружење ученика, односно, потребно је размотрити утицаје свих облика културног капитала.

У нашем истраживању културног капитала, самоефикасности и образовног постигнућа спровели смо секундарну анализу емпиријске грађе прикупљене у оквиру студије PISA 2009. Узорак је обухватио 4843 ученика средњих школа у Србији у узрасту од 15 година. Културни капитал операционализован је у сва три облика помоћу индикатора који су се налазили у упитнику за ученике. Инситуционализовани културни капитал ученика мерен је помоћу образовних квалификација оца. Број 
књига које испитаник поседује у свом дому, као и поседовање других предмета намењених културној потрошњи, као што су слике и образовни софтвери, послужили су за мерење опредмећеног културног капитала. Отеловљени облик културног капитала испитиван је кроз читалачке навике испитаника. Самоефикасност је мерена скалом која се налазила у додатном упитнику за ученике.

Резултати су показали да са растом нивоа отеловљеног културног капитала расте и самоефикасност. Самоефикасност ученика показала се као значајан чинилац за резултате научне писмености што говори у прилог Бандуриној теорији самоефикасности, која у домену образовања наглашава важност процењивања личне ефикасности ученика за успешно учење и развој индивидуалних компетенција.

Налази који се односе на релације између културног капитала и научне писмености указују на то да отеловљени и опредмећени културни капитал значајно доприносе предикцији ученичких постигнућа на овом пољу.

На основу наведеног, у овом нашем истраживању, које је за циљ имало испитивање веза између културног капитала, самоефикасности и постигнућа на PISA тесту, потврдили смо присуство тестираних релација. Међутим, с обзиром на то да добијене везе нису високог инетензитета, може се закључити да и други чиниоци имају улогу у развоју самоефикасности и постигнућа код ученика. 